\title{
On the Problem of Dialectics of Basic Models of Good and Evil in the Process of Social and Cultural Communication
}

\author{
Evgenia V. Ivanova* \\ Ural Federal University named after the B.N. Yeltsin \\ 51 Lenin, Ekaterinburg, 620083, Russia
}

Received 20.12.2014, received in revised form 17.01.2015, accepted 26.02.2015

This article is dedicated to the analysis of dialectical interplay of such essential aspects of life in the modern world as good and evil. Is there such thing as "the absolute good" or "the absolute evil"? Why are infernal heroes so popular on contemporary myth-making? The author defines the basic philosophical models of the relationship between good and evil in social and cultural communications.

Keywords: myth, religion, good, evil, social and cultural communication, religious mythology, religious ethics.

Research area: philosophy.

Introduction. Social and cultural communication is the process of interaction between subjects of social and cultural activities with the purpose of sharing information. In cultural studies there are four basic types of social and cultural communication. The first one is innovative, which implies the exposure of cultural subjects to new forms of knowledge and experience. The second is orientational, which helps cultural subjects adapt to the system of influences that are predominant at the moment. The third is stimulative, which affects cultural subjects by activating their potential. The fourth is correlative, which helps to specify certain parameters of cultural activities. All these types of social and cultural communication are involved in contemporary process of cultural dialogue. This implies that the uniqueness of different cultures suggests bidirectional relationship rather than confrontation. Furthermore, this process is aided by aspects of social and cultural communication. This is particularly important for the dialogue and "symphonic" nature of religious cultures, which are based on religious ethics, or more simply the problems of interpretation of such concepts as "good" and "evil".

Materials and methods. Speaking of dialectics of good and evil, it can be emphasized that any notion can be considered evil by some people and vice versa by the others. This stance is determined by social status, interests, education and other cultural conditions. In fact, the same phenomenon may, to a different extent, vary between good and evil depending on the context and stage of development. Such relationship can be called a "relative" model. This model was

(C) Siberian Federal University. All rights reserved

* Corresponding author E-mail address: ieviev@mail.ru 
mentioned by various medieval philosophers, including M. Montaigne in his essay "On Experience". It is based on a statement that all human states and emotions are subjective and may at any time change to the opposite. However, we are primarily interested in religious and ethical models, as they play a more significant role in the processes of cross-cultural communication.

The first model is clearly manifested in the Abrahamic religions, although certain prerequisites for its development can also be found in nation-specific religions, such as Zoroastrianism. This model represents religious dualism of good and evil, expressed in their eternal conflict. As a result, the world is perceived through binary oppositions, as "friend-or-foe", "right-orwrong", "peace-or-war". Having emerged from religious mythology, these oppositions still stand in the way of tolerant attitude towards different religious and other values and behavior patterns.

This model is well-developed by J. Boehme in his work Aurora: the Rising of Dawn. According to Boehme, till the Last Judgment the nature embraces two inclinations: one-graceful, heavenly and godly, and the other - wicked, diabolical and ravenous. Both confront each other furiously, but one does not exist without the other. A dual source, good and evil in all things, stems from the stars. Through this source everything has its great mobility, its course, impulse and growth. "Yes" and "no", "good" and "evil" are two opposites of one objective reality, as regarded by this philosopher. Beyond these two inclinations, which are constantly struggling against each other, all things would be nothing, would stop and not move (Boehme J., 2008, p. 25). According to Boehme, a human is both "the lesser world" and "the lesser God", embodying the world, the nature and the God in all their complexity and ambiguity. Thus, good and evil are fighting within a human, who lives in peace with both of them. And yet, good turns into evil as easily as evil into good. So obviously these are two complementary substances, one - of God and the other - of Lucifer, which are constantly struggling against each other, giving birth to the multitude of all things.

In this model, one of the main infernal heroes is the devil. As a mythological and religious archetype, he represents evil as something extrinsic to people. He is a sort of a blind force independent, foreign, unpredictable and imposed by the world of chaos. He also represents the inner evil, which has its root in humanity itself, when people misunderstand the free will given to them by the God. So, without a doubt, one of the major functions of the devil is to make humans comprehend universal values in a negative sense.

The same happens with a person, who steps over a certain line and starts fostering selfishness, ambition and pride, while the latter, in its early stages, is the spawn of vanity, arrogance and hubris.

Consequently, the first model of religious and ethical dualism suggests the confrontation between two standalone and antagonistic substances, which governs their interrelationship. "What would your good do, if evil didn't exist?" is a famous question of one of the infernal heroes in M. Bulgakov's novel Master and Margarita.

It appears that in contemporary social, cultural and political communications this model is a predominant one. There are always symbols with positive and negative markings: protagonist and antagonist, friends and foes, believers and disbelievers. "War is the father of all and king of all". The common thought regards this war of two opposing inclinations in absolute terms, exemplified by the archetypes of war, swordlaw and outsiders. On the other hand, something regarded as "good", that is bearing a positive aspect, is overemphasized as the archetype of the ultimate truth. In such a model, there is no space for a dialogue, but only for intervention 
and suppression of what seems wrong. Is there a chance for cultural communication within this model? In N. Y. Danilevsky's apt words, this intercultural model rather suggests "weeding" of a foreign culture. In such a case, communication is accomplished by an algorithm of dialectical interplay between absorption and alienation. However, according to D. V. Pivovarov, "not nearly any alienation is necessarily negative, leads to the loss of freedom and contradicts freedom. Not any, but only particular alienation is antihuman, involves depersonalization, inanity, tragedies and sorrows" (Pivovarov D. V., 2009, p. 134).

The second model of opposition between good and evil is "evil as intentionally inverted good", or the inclination away from good, which is often encountered in the mundane consciousness of men, as well as in religious mythology. In the second model, the effect of relativity and ethical subjectivity is amplified. Let's describe it in the context of development of the "coven" concept. Cultural stereotypes have traditionally characterized a coven through negative ethical markings. But this ethical "minus" originated from the rivalry and active struggle between two different images. The first image emerged from the medieval academic culture (judges, demonologists and the Inquisition). It was based on the assumption of the existence of a hostile sect, acting at the instigation of the devil, with its initiates violating the cross and the sacraments upon joining. The second image has its roots in the mythological world model and is based on the belief in the extraordinary abilities of certain people, either male or female, who enter a state of ecstasy, assuming the form of an animal or sitting on top of an animal, and venture into the underworld to bring prosperity to their communities. These entranced mediators between two worlds fight their foes, known under many names (but mostly called warlocks and the dead), for many purposes (land fertility, healing the diseased, knowledge of the future). These purposes have always had social meaning (even in the latest witch trials we can come across some unusual, in terms of demonological stereotypes, details, such as flying to a coven on top of a wheat ear or a grass stalk). However, academic or theological thought is always triumphant, proclaiming all members of a coven as absolutely evil and thus developing antagonistic image of a witch (Ivanova E. V., 2002, p. 57).

This model is very close to the first one, but its focus is emphasized on another device of relativity - inversion. Inversion, as one of the methods of religious mythology, has already been studies by the author of this article (Ivanova E.V., 2012, P.56). "Modern infernal heroes are not negative, foul or repellent. On the contrary, as the result of inversion, as one of the methods of religious mythology, they became attractive role models for many admirers and movie fans, as well as readers of novels, on which these movies are based" (Ivanova E. V., 2013, p. 197-198). Inversion shows that "evil as intentionally inverted good" is horrible and monstrous on its surface, but if there is possibility to get to the bottom of this notion and analyze it philosophically, then it is also possible to return to the good side both within a person and in society. Maybe the reason we find infernal heroes attractive is that they do not resemble "petrified mythical species" of medieval monsters or the models of horror movies.

So, having analyzed the first two models of dialectical interplay between good and evil, the first one can be conditionally labeled as disjunctive, based on the principle "either good or evil, a third is not given", while the second one can be labeled as conjunctive (both good and evil; good but also evil; etc.).

The third model of correlation between good and evil reveals itself in the Baha'i faith. In this case, good is identified with well-being, and so evil is viewed as imperfection of existence. 
According to the doctrine of God's unity, the followers of this faith conclude that evil cannot exist on its own, since the infinite truth is one. Just as darkness is the absence or a small amount of light, evil is the absence or a rudimentary state of good. Evil represents nonexistence. That is why in the Baha'i faith there is no need in personification of the evil forces, or the infernal forces that are engaged in tempting human beings. Consequently, evil does not exist; there is only imperfection of good. Such evil is secondary to the forces of good, resulting from the misuse of these forces that are an inherent part of good.

The fourth model is proclaimed in the Eastern religion and philosophy - Taoism. Tao, unlike the Greek Logos, does not perceive existence in terms of opposite tendencies, but follows the spontaneous rhythm of the world, where one succeeds another, and the day goes after the night. According to Taoism, this path leads towards the good (Thompson M., 2000, p. 256).

Yin and yang in the strict sense are not opposite to each other, but existing in one another. The fundamental concept of Tao Te Ching is the path of nonviolence, non-disturbance of the way things are, the path of natural rhythm - following the moral law of Tao and smooth transition from one to another. Our consciousness is based on this natural rhythm, on the constant succession of phases. One does not fight the other to destroy it. Everything happens in the right time and then passes away. Chinese sages tried not so much to achieve wholeness as not to disturb the Unity or the Path. This can be done only by avoiding a rupture and turning back at the proper time, because yin and yang are both growing in strength; on the edge of the Supreme Ultimate they are changing places, just as light and darkness, heat and cold, good and evil. So the underlying principle is to maintain balance and avoid any interference with existence.
Nothing is unidirectional, univocal; everything is both yin and yang, both active and passive at the same time. Thus, the principles of yin and yang are both the transition from one state to another and the structure of things. Natural phenomena are defined by this relationship of yin and yang, which are constantly circling around each other, existing in one another. One does not exist without the other, just as breathing in and breathing out. The goal is to achieve the golden mean - modus in rebus. In order not to disturb Tao, not to disrupt the Unity, one must turn back at the proper time and act in unison with nature.

In the times of Lao Tzu the Chinese did not have a notion of "opposition", since yin and yang in the strict sense are not opposite to each other, but existing in one another, creating such bond in everything - a bond of smooth transition and interchange without any confrontation and conflict. There is a balance in everything; if one side suppressed the other, it would lead to the disruption of the Unity, the infinite thread of Tao would be torn. If one side didn't balance the other and supposedly duplicated, resulting in two yins or two yangs, it would ruin the Unity. That is why the Eastern sages were so much concerned with the Law of the Middle (chung), or the balance, regarding it as the primary condition of the Unity. And so people follow this natural way of Tao.

Thus, Tao (the Absolute) is the universal law, manifested in yin and yang. The emphasis in a triad "Tao-good-evil" is made on good, but according to the principle of equilibrium, good and evil are then equally balanced.

In terms of Taoism, evil is the disturbance of the course of nature, harmony, or Tao. It is kind of cosmic evil (the Chaos), which is confronted by Tao (the Good). On the other hand, the interchange of good and evil is harmoniously interlaced within Tao, just as spring turns into 
summer, bad into good, fortune into misfortune. It is evident in the very idea of oscillation going back and forth. When people see some things as beautiful, other things become ugly. When people see some things as good, other things become bad. Hence, existence and nonexistence spawn from each other, the long and the short relate to each other, the high and the low are directed towards each other.

In other words, Tao as the fundamental principle of the world embodies a strict causality between people and nature - kind of a butterfly effect. Every single deed or misdeed will have its consequences - and all the more so for the latter, which leads to the disturbance of natural phenomena (for example, the interchange of heat and cold "yang-chi" and "yin-chi", which leads to natural disasters and famine).

So Tao is the universal Law and the Absolute. It is the way of nature and inner law, by which nature evolves. De is the manifested strength and might, reigning over nature together with Tao and granting all creatures the ability to live free of corruption and untimely death, provided that the main law of Tao is not violated. "De feeds everything", while yin and yang, which "Tao bears in its mouth", are the principles that ensure the wholeness of the world and all things (Thompson M., 2000, p. 260).

In the process of social and cultural communication, the native and the Western cultures are also interested in this model of correlation between the key ethical categories, as well as the mysterious principle of "wu wei" or non-action. Everything has its natural course; according to the law of Tao, a person should wait and take time before making a decision. Any attempt to intervene, to rush to the fight to uphold justice, to try altering something from your own angle, will have a trivial consequence - "we wanted the best, you know the rest". Chuang Tzu argued that one should only act when that action can be a priori effective; if nothing can be done, nothing should be done (Thompson M., 2000, p.274). Surely, for a person living among social communications of a practical culture of constant dynamic transformation the question of thinking before interfering ("Is my effort really required here?") is answered in favor of the first model of interplay between good and evil - "we'll do and we'll see". The ethical issues in terms of nonviolence are still to be discussed.

The fifth model of dialectics of good and evil is also present in the Eastern thought, specifically in Indian philosophy. Evil is viewed as the remoteness from good; however, it is possible to approach good by intentionally cultivating three complementary factors: perception, behavior and concentration. In Indian philosophy, knowledge and virtue are considered integral not only because virtue or righteousness depend on the knowledge of what is good according to the philosophers, but also because the development of perception does not seem possible without the intentional control of one's passions and prejudices.

Thus, in Chinese and Indian religious thought, evil does not possess an ontological essence; it is suggested that evil is the remoteness from the core of the good, a bent beam from the Source, the absence of good. The only way to salvation is through not interfering with the Taothe "middle way" to nirvana without disturbing nature's harmony.

Results. So, having analyzed the dialectics of good and evil in various religious cultures, we have highlighted five basic models:

The first model, based on the principle "either good or evil, a third is not given", was conditionally labeled as disjunctive.

The second model was labeled as conjunctive ("evil as intentionally inverted good", inclination away from good or towards good).

The third model is "evil as the absence or a rudimentary state of good". 
The fourth is the interdependence and interaction of the ethical opposites, which denies their absolute distinction.

The fifth is "evil as the remoteness from good".

Surely, these models are conditional and distinguished in terms of philosophical reflection for further elaboration.

Conclusions. In the process of social and cultural communication between Western and Eastern cultures, the Western culture takes a great interest in the Eastern values. For the sake of reviewing multiple standpoints in a dialogue of cultures, it seems feasible to address the key ethical categories of good and evil, which, as we have shown, do not have a strict binary opposition, but rather suggest deeper dialectical algorithms. As these categories define human actions, it is from this emphasis on multiple approaches to the assessment of these actions that we should start searching for the fundamentals of multiconceptuality and dialogue in humanities.

\title{
References
}

1. Boehme J. Aurora: the Rising of Dawn. M., 2008. 416 p.

2. Ivanova E. V. Contemporary infernal cultural hero as an element of religious mythology. Siberian Federal University Journal, Humanities 2 (2013, 6), p. 194-201.

3. Ivanova E. V. "Religious fantasy" as an element of contemporary religious mythology. Siberian Federal University Journal, Humanities 1 (2012, 5), p. 56-62.

4. Ivanova E. V. Witches. Scientific narrative on the archetypes of women's behavior. Yekaterinburg, 2002. $129 \mathrm{p}$.

5. Pivovarov D. V. Ontology of religion. SPb., 2009. 505 p.

6. Thompson M. Eastern philosophy. M., 2000. 579 p.

\section{К проблеме диалектики основных моделей добра и зла в процессе социокультурной коммуникации}

\author{
Е.В. Иванова \\ Уральский федеральный университет им. Б.Н. Ельцина \\ Россия 620083, Екатеринбург, пр. Ленина, 51
}

\begin{abstract}
Статья посвящена анализу диалектического взаимодействия таких важнейших сторон жизни современного человека, как добро и зло. Возможно ли «абсолютное добро» и есть ли «абсолютное зло»? Почему так привлекательньл инфернальные герои в современном мифотворчестве? Автор формулирует основные философские модели взаимоотношения добра и зла в социокультурных коммуникациях.
\end{abstract}

Ключевые слова: миф, религия, добро, зло, сочиокультурная коммуникация, религиозная мифология, религиозная этика.

Научная специальность: 09.00.00 - философские науки. 